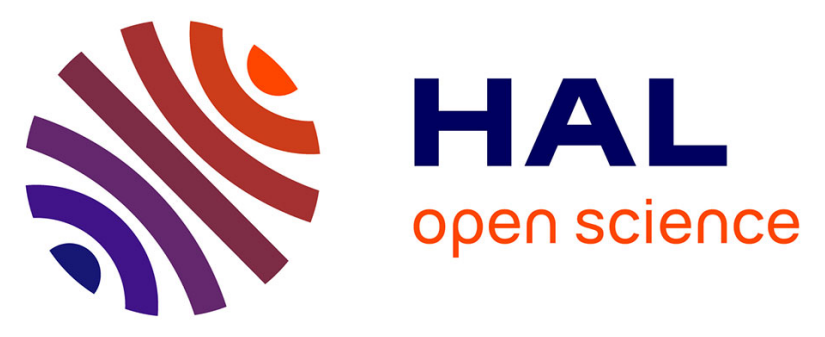

\title{
Lanthanide Cation Binding Properties of Homooxacalixarene Diethylamide Derivatives
}

Paula Maria Marcos, Manuel António Segurado, José Rosário Ascenso, Peter J. Cragg, Sylvia Michel, Veronique Hubscher, Françoise Arnaud-Neu

\section{- To cite this version:}

Paula Maria Marcos, Manuel António Segurado, José Rosário Ascenso, Peter J. Cragg, Sylvia Michel, et al.. Lanthanide Cation Binding Properties of Homooxacalixarene Diethylamide Derivatives. Supramolecular Chemistry, 2011, 23 (01-02), pp.93-101. 10.1080/10610278.2010.510562 . hal00672790

\section{HAL Id: hal-00672790 \\ https://hal.science/hal-00672790}

Submitted on 22 Feb 2012

HAL is a multi-disciplinary open access archive for the deposit and dissemination of scientific research documents, whether they are published or not. The documents may come from teaching and research institutions in France or abroad, or from public or private research centers.
L'archive ouverte pluridisciplinaire $\mathbf{H A L}$, est destinée au dépôt et à la diffusion de documents scientifiques de niveau recherche, publiés ou non, émanant des établissements d'enseignement et de recherche français ou étrangers, des laboratoires publics ou privés. 


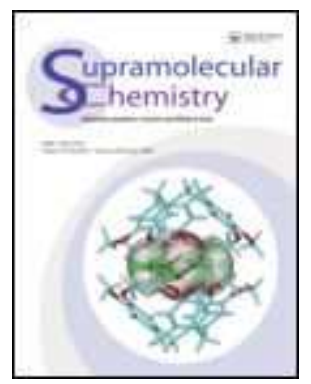

\section{Lanthanide Cation Binding Properties of Homooxacalixarene Diethylamide Derivatives}

\begin{tabular}{|c|c|}
\hline Journal: & Supramolecular Chemistry \\
\hline Manuscript ID: & GSCH-2010-0133.R1 \\
\hline Manuscript Type: & Special Issue Paper \\
\hline $\begin{array}{r}\text { Date Submitted by the } \\
\text { Author: }\end{array}$ & 14-Jul-2010 \\
\hline Complete List of Authors: & $\begin{array}{l}\text { Marcos, Paula; Universidade de Lisboa, Chemistry Department } \\
\text { Segurado, Manuel; FFUL, CCMM } \\
\text { Ascenso, José; IST, Chemistry } \\
\text { Cragg, Peter; University of Brighton } \\
\text { Michel, Sylvia; University of Strasbourg } \\
\text { Hubscher, Veronique; ECPM/ULP, LCP } \\
\text { Arnaud-Neu, Françoise; Universite' Louis PasteursEcole } \\
\text { Europeenne Chimie Polymeres Materiaux }\end{array}$ \\
\hline Keywords: & $\begin{array}{l}\text { dihomooxacalix[4]arene, Hexahomotrioxacalix[3]arene, } \\
\text { Diethylamide derivative, Lanthanide cation binding, Proton NMR } \\
\text { titration }\end{array}$ \\
\hline
\end{tabular}

\section{S) ScholaroNE \\ Manuscript Central}


1

2

3

4

5

6

7

8

9

10

11

12

13

14

15

16

17

18

19

20

21

\section{Lanthanide cation binding properties of} homooxacalixarene diethylamide derivatives

Paula M. Marcos, José R. Ascenso, Manuel A. P. Segurado, Peter J. Cragg, Sylvia Michel, Véronique Hubscher-Bruder and Françoise Arnaud-Neu

The binding properties of $\mathbf{1 b}, \mathbf{2} \mathbf{b}$ and $\mathbf{3 b}$ towards lanthanide cations were assessed by stability constant measurements in methanol and also by extraction, proton NMR and microcalorimetric studies.

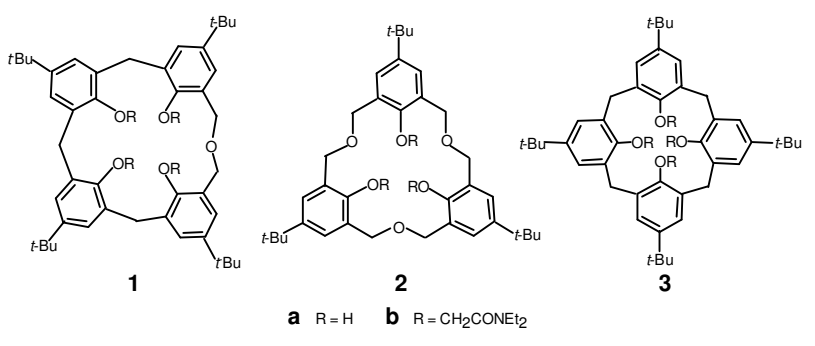




\section{Graphical Abstract}

\section{Lanthanide cation binding properties of homooxacalixarene diethylamide derivatives}

Paula M. Marcos, José R. Ascenso, Manuel A. P. Segurado, Peter J. Cragg, Sylvia Michel, Véronique Hubscher-Bruder and Françoise Arnaud-Neu

The binding properties of $\mathbf{1 b}, \mathbf{2} \mathbf{b}$ and $\mathbf{3 b}$ towards lanthanide cations were assessed by stability constant measurements in methanol and also by extraction, proton NMR and microcalorimetric studies.

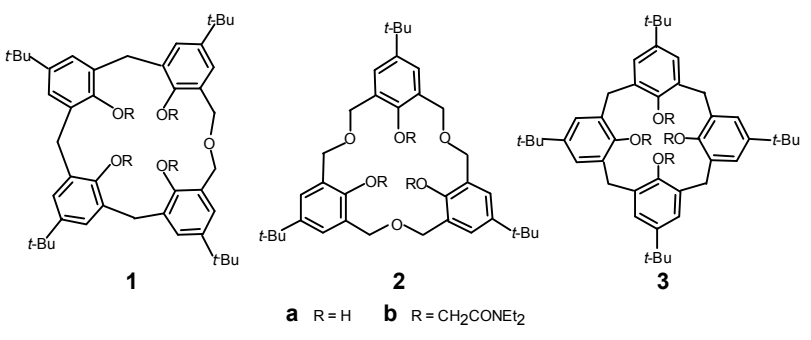




\title{
Lanthanide Cation Binding Properties of Homooxacalixarene Diethylamide Derivatives
}

\author{
Paula M. Marcos, ${ }^{\text {ac }}$ José R. Ascenso, ${ }^{\mathrm{b}}$ Manuel A. P. Segurado, ${ }^{\mathrm{ac}}$ Peter J. Cragg, ${ }^{\mathrm{d}}$ \\ Sylvia Michel, ${ }^{\mathrm{e}}$ Véronique Hubscher-Bruder ${ }^{\mathrm{e}}$ and Françoise Arnaud-Neu ${ }^{\mathrm{e}}$ \\ ${ }^{a}$ Centro de Ciências Moleculares e Materiais, Faculdade de Ciências da Universidade de Lisboa, \\ Edifício C8, 1749-016 Lisboa, Portugal. \\ ${ }^{b}$ Instituto Superior Técnico, Complexo I, Av. Rovisco Pais, 1049-001 Lisboa, Portugal \\ ${ }^{c}$ Faculdade de Farmácia da Universidade de Lisboa, Av. Prof. Gama Pinto, 1649-003 Lisboa, \\ Portugal \\ ${ }^{d}$ School of Pharmacy and Biomolecular Sciences, University of Brighton, Brighton BN2 4GJ, UK \\ ${ }^{e}$ Université de Strasbourg, IPHC, 25 rue Becquerel 67087 Strasbourg, France \\ CNRS, UMR7178, 67037 Strasbourg, France.
}

\section{Corresponding author:}

\section{Paula M. Marcos}

Centro de Ciências Moleculares e Materiais,

Faculdade de Ciências da Universidade de Lisboa,

Edifício C8, 1749-016 Lisboa, Portugal.

E-mail: pmmarcos@fc.ul.pt 


\begin{abstract}
The binding properties of two homooxacalixarene diethylamides (1) and $\mathbf{2 b})$ derived from $p$ tert-butyldihomooxacalix[4]arene and p-tert-butylhexahomotrioxacalix[3]arene respectively, in the cone conformation, for lanthanide cations were investigated. These properties were assessed by extraction studies of the metal picrates from water into dichloromethane and stability constant measurements in methanol, using spectrophotometric and potentiometric techniques. Microcalorimetric studies of $\mathrm{La}^{3+}, \mathrm{Pr}^{3+}, \mathrm{Eu}^{3+}$ and $\mathrm{Gd}^{3+}$ complexes in the same solvent were also performed. Proton NMR titrations with the representative lanthanides $\mathrm{La}^{3+}$, $\mathrm{Eu}^{3+}$ and $\mathrm{Yb}^{3+}$ were also carried out to establish the sites of interaction of the ligands with the cations. The analogous derivative (3b) of p-tert-butylcalix[4]arene was also studied and the results of the three compounds are compared. Diethylamide $\mathbf{1 b}$ is the strongest binder, showing some preference for the light lanthanides in extraction, but exhibiting practically no selectivity in complexation. 1b displays the highest stability constant values ever found with this ligand $(\log \beta=8.6-9.2)$. In contrast, $2 \mathbf{b}$ shows lower extraction and stability constant values, but it is a more selective ligand, showing a clearer preference for the light lanthanides. Diethylamide 3b exhibits a similar behaviour to that of its analogous 1b. Proton NMR titrations confirm the formation of 1:1 complexes between the amides and the cations studied, also indicating that they should be located inside the cavity defined by the phenoxy and the carbonyl oxygen atoms.
\end{abstract}

Keywords: Dihomooxacalix[4]arene; Hexahomotrioxacalix[3]arene; Diethylamide derivative; Lanthanide cation binding; Proton NMR titration. 


\section{Introduction}

More than 30 years after the beginning of modern calixarene chemistry, calixarenes (1-3) continue attracting much attention as ion receptors and carriers in host-guest chemistry. The parent compounds are readily available and can be further functionalised on the upper and lower rims to give a large variety of derivatives.

In particular, the ability of carbonyl containing substituents on the lower rim of calixarenes to bind metal ions, predominantly alkali and alkaline earth (4), but also transition and heavy metal cations (5), has been largely studied. Besides these mono and divalent cations, research work with trivalent cations, namely lanthanides $(6,7)$, has also been increasingly reported. The growing interest in these elements is mainly due to their use in materials for catalysis, optics, electronics, in luminescent probes, in biology and in medicine as contrast agents for magnetic resonance imaging. The study of the interactions between calixarenes and lanthanides is also motivated by the treatment of radioactive wastes, which requires the extraction of lanthanides and actinides from acidic effluents, followed by their separation before the disposal or the transmutation of the actinides into short-lived radionuclides.

Lanthanide ions, being hard Lewis acids (8), show strong affinity towards hard oxygen donor atoms. Thus, it is expected that calixarenes containing such donor atoms are potential receptors for those cations. Phosphorylated calix[4]arenes, bearing carbamoylmethylphosphine oxides (CMPO) $(6 a, b, 9,10)$ moieties on the upper and lower rims or phosphine oxide $(11,12)$, as well as calix[4]arene derivatives with lower rim carbonyl containing substituents, such as esters (13), carboxylic acids (13-15) and amides (16-18), have been used as extracting agents for lanthanide ions. Also the larger and more flexible calix[6]- $(18,19)$ and calix[8]arenes (18-20) have been investigated, since lanthanide cations require high 
coordination numbers ( 8 or 9 ) and, therefore, more donor sites can be favourable to their complexation.

Both dihomooxacalix[4]arene and hexahomotrioxacalix[3]arene, calixarene analogues in which one or all $\mathrm{CH}_{2}$ bridges are replaced by $\mathrm{CH}_{2} \mathrm{OCH}_{2}$ groups respectively, are more flexible molecules than calix[4]arenes, but still possess a cone conformation, the most appropriate for complexation. In the course of the studies of binding and transport properties of homooxacalixarenes bearing carbonyl groups at the lower rim, namely the amide function $(21,22)$, towards alkali, alkaline earth, transition and heavy metal cations, we have recently extended our research into lanthanide ions (23).

This paper reports the binding properties of two diethylamides, $\mathbf{1 b}(24)$ and $\mathbf{2 b}$ (25), derivatives of $p$-tert-butyldihomooxacalix[4]arene (1a) and of p-tert-butylhexahomotrioxacalix[3] arene (2a) respectively (Figure 1), in the cone conformation, towards lanthanide cations $\left(\mathrm{La}^{3+}, \mathrm{Ce}^{3+}, \mathrm{Pr}^{3+}, \mathrm{Nd}^{3+}, \mathrm{Sm}^{3+}, \mathrm{Eu}^{3+}, \mathrm{Gd}^{3+}, \mathrm{Dy}^{3+}, \mathrm{Er}^{3+}\right.$ and $\left.\mathrm{Yb}^{3+}\right)$. Extraction studies of metal picrates from an aqueous solution into dichloromethane and stability constant measurements in methanol based on UV absorption spectrophotometry and competitive potentiometry were performed. Thermodynamic parameters of $\mathrm{La}^{3+}, \mathrm{Pr}^{3+}, \mathrm{Eu}^{3+}$ and $\mathrm{Gd}^{3+}$ complexation were determined by microcalorimetric titrations. The affinity of the ligands for $\mathrm{La}^{3+}, \mathrm{Eu}^{3+}$ and $\mathrm{Yb}^{3+}$ cations has also been investigated by proton NMR spectrometry, mainly to establish the binding sites. Those three cations were chosen as representatives of the light, middle and heavy categories of the lanthanide series. The diethylamide (3b) (26) derivative of p-tert-butylcalix[4]arene (3a) is also studied in this work and the results of the three derivatives are compared and discussed in terms of the size and conformational effects of the macrocycles. 


\section{Results and discussion}

\section{Extraction studies}

The ionophoric properties of diethylamides $\mathbf{1 b}, \mathbf{2 b}$ and $\mathbf{3 b}$, all in the cone conformation, towards lanthanide cations were first evaluated by the standard picrate method (27). The results, expressed as percentages of cation extracted $(\% E)$, are collected in Table 1.

The data reveal that amide 1b displays very high extraction levels for all the cations (\% $E$ ranges from 41 to 76 ). These values are significantly higher (more than double) than those obtained for amide $\mathbf{2 b}$ ( $\% E$ ranges from 13 to 34$)$, the maximum difference being observed in the cases of $\mathrm{Er}^{3+}$ and $\mathrm{Dy}^{3+}$ cations. This behaviour was expected as lanthanides require high coordination numbers ( 8 or 9 ) and $\mathbf{2 b}$ possesses only three amide groups, and consequently only six donating sites can surround the cations, compared to the eight sites of tetraamide $\mathbf{1 b}$. However, $\mathbf{2 b}$ is a more selective extractant agent than $\mathbf{1 b}$ (for example, $S_{\mathrm{Pr}}{ }^{3+} / \mathrm{Yb}{ }^{3+}=2.6$ and 1.8, respectively, where selectivity $\left.S=\% E_{\mathrm{M} 1}{ }^{3+} / \% E_{\mathrm{M} 2}{ }^{3+}\right)$. Derivative $\mathbf{1 b}$ also shows a much higher extraction percentage than that of the amide $\mathbf{3 b}$ ( $\% E$ ranges from 12 to 24). Moreover, compared to the extraction percentages of europium picrate (the only data found in the literature) $(4 a)$ with the larger calix[5]- $(24 \% E)$ and calix[6]arene $(39 \% E)$ amide analogues, we verify that $\mathbf{1 b}$ still displays the highest values.

Both amides $\mathbf{1 b}$ and $\mathbf{2 b}$ show similar extraction profiles. They do not display any peak selectivity among the cations, but they clearly discriminate between the light and the heavy lanthanides. The former cations (from $\mathrm{La}^{3+}$ to $\mathrm{Eu}^{3+}$ ) are preferred over the latter (with exception of $\mathbf{1 b}$ with $\mathrm{Dy}^{3+}$ ), and among those a very slight selectivity can be observed for $\mathrm{Pr}^{3+}, \mathrm{Nd}^{3+}$ and $\mathrm{Ce}^{3+}$ with both derivatives, and also for $\mathrm{Eu}^{3+}$ with $\mathbf{1 b}$. Despite the small variations among the ionic radii of the lanthanide ions $\left(0.16 \AA\right.$ from $\mathrm{La}^{3+}$ to $\left.\mathrm{Yb}^{3+}\right)$, the relative larger size of those cations may account for these differences, as both derivatives have been 
showing a stronger affinity for the larger cations $(21,22)$. This extraction trend is, however, the opposite of that found by us for the corresponding ketone derivatives (23). In the case of amide $\mathbf{3 b}$, the extraction profile is slightly different. This derivative does not display any peak of selectivity either, but shows preference for the middle lanthanides, as $\mathrm{Eu}^{3+}, \mathrm{Sm}^{3+}$ and $\mathrm{Dy}^{3+}$.

\section{Complexation studies}

The complexation of some representative lanthanide cations $\left(\mathrm{La}^{3+}, \mathrm{Pr}^{3+}, \mathrm{Eu}^{3+}, \mathrm{Gd}^{3+}\right.$ and $\left.\mathrm{Yb}^{3+}\right)$ was followed by UV absorption spectrophotometry and/or competitive potentiometry for ligands $\mathbf{1 b}, \mathbf{2 b}$ and $\mathbf{3 b}$ in methanol. The logarithms of the stability constants $\beta$ of the $1: 1$ complexes formed are given in Table 2. For all these cations except $\mathrm{Yb}^{3+}$, the complexation thermodynamic parameters were determined by microcalorimetry with ligands $\mathbf{1 b}$ and $\mathbf{2} \mathbf{b}$ in the same solvent. These data are collected in Table 3.

The first results were obtained with the lanthanide chlorides by spectrophotometry in the presence of tetraethylammonium chloride as the supporting electrolyte. Very significant spectral changes were observed in the spectrum of $\mathbf{1 b}$ during its titration against the metal salts, until the metal to ligand concentration ratio reaches 1 , indicating the formation of very stable 1:1 complexes (Figure 2). With the hexahomotrioxacalix[3]arene 2b, much weaker spectral variations could be noticed. In contrast to $\mathbf{1 b}$, for which only a lower limit could be estimated ( $\log \beta \geq 7$ ), the interpretation of the experimental data for $\mathbf{2 b}$ led to reliable stability constants for the 1:1 complexes (Table 2).

As the stability constants obtained with $\mathbf{1 b}$ and metal chlorides were too high, and at the limits of the experimental method, it was decided to follow the complexation of lanthanide nitrates in the presence of $\mathrm{Et}_{4} \mathrm{NNO}_{3}$ as the supporting electrolyte. Previous studies on phosphorylated calixarene derivatives showed an important decrease of the stability 
In order to better assess the high stability constants of the complexes with $\mathbf{1 b}$, potentiometric experiments based on a competition with the $\mathrm{Ag}^{+}$cation were then performed with lanthanide trifluoromethanesulfonates (triflates) in the presence of $\mathrm{Et}_{4} \mathrm{NClO}_{4}$ as the supporting electrolyte. The stability constant of the $1: 1 \mathrm{Ag}^{+}$complex has been re-evaluated and the result $(\log \beta=7.16)$ found is in excellent agreement with the value published earlier (21). For comparison the stability constants of the 1:1 complexes with p-tertbutylcalix[4]arene tetra(diethyl)amide $\mathbf{3 b}$ were also determined for $\mathrm{Ag}^{+}$and for the selection of lanthanides studied. The values for $\mathrm{Ag}^{+}(\log \beta=7.56)$ and for $\mathrm{Pr}^{3+}, \mathrm{Eu}^{3+}$ and $\mathrm{Yb}^{3+}$ complexes (Table 2) are consistent with those published earlier $(28,4 a)$.

In order to get a better insight into the origin of the stability of these complexes, the complexation of $\mathrm{La}^{3+}, \mathrm{Pr}^{3+}, \mathrm{Eu}^{3+}$ and $\mathrm{Gd}^{3+}$ triflates and of $\mathrm{La}^{3+}$ nitrate was followed by microcalorimetric experiments, which allowed the determination of the complexation thermodynamic parameters. $\mathrm{Yb}^{3+}$ triflate was not soluble enough to obtain significant heat effects during the titrations of the ligands with this cation. Therefore, no data could be derived in this case. With $\mathbf{1 b}$, the thermograms were simple, showing exothermic heat signals until a 1:1 stoichiometry was reached, as illustrated in the case of $\mathrm{Gd}^{3+}$ (Figure 3). They are consistent with the formation of very stable $1: 1$ complexes, in agreement with the spectrophotometric and potentiometric results. The enthalpies of complexation, $\Delta H$, determined from the slopes of the cumulative heat effects versus the number of moles of reactant added, and the corresponding entropies of complexation, $\Delta S$, calculated from the 
Gibbs energy derived from the stability constants obtained from potentiometry are listed in Table 3. With $\mathbf{2 b}$, the thermograms are quite different showing endothermic effects, as for example for $\mathrm{Gd}^{3+}$ (Figure 4). In this case, both the logarithm of the stability constants and the enthalpy of complexation could be refined simultaneously (Table 3). The stability constants were found to be slightly higher than those determined by spectrophotometry with chloride counterions. With $\mathbf{3 b}$ and all the lanthanides studied, the thermograms were more complex: they started with exothermic signals, becoming endothermic from a metal to ligand concentration ratio of 0.7 and exothermic again, corresponding to the dilution effect, after the 1:1 stoichiometry. They are certainly consistent with several complexation processes, including the formation of a 1:1 complex as with the other ligands studied. They may also show, at some extent, micro-precipitation, which could be the reason why they could not be interpreted.

The main conclusions are the following:

(i) The dihomooxa derivative $\mathbf{1 b}$ shows a higher affinity for lanthanides than its hexahomotrioxa counterpart $\mathbf{2 b}$. For instance, the $\mathrm{Eu}^{3+}$ complex is at least 2.3 log units higher with 1b than with $\mathbf{2 b}$ with chloride counterions and 4 log units higher with nitrate counterions. This is consistent with the remarkable extraction efficiency of $\mathbf{1 b}$ as compared with $\mathbf{2 b}$. In contrast, there is no great difference in stability between the complexes with $\mathbf{1 b}$ and its calix[4]arene counterpart $\mathbf{3 b}, \log \beta$ values being in the ranges $9.2-8.6$ and $8.9-8.2$, respectively.

(ii) The stability of the complexes is strongly dependent on the medium. As expected from the coordinating properties of the anions towards lanthanides in methanol (29), the complexes are less stable in the presence of nitrate ions than in the presence of the less coordinating 
(iv) With 1b, the stabilization of the complexes is driven by the enthalpy and the entropy changes which vary irregularly from $\mathrm{La}^{3+}$ to $\mathrm{Gd}^{3+}$. The former are clearly negative, ranging from -24.78 to $-31.77 \mathrm{~kJ} \mathrm{~mol}^{-1}$, and the latter clearly positive, ranging from 21 to $25.78 \mathrm{~kJ}$ $\mathrm{mol}^{-1}$, being hence both favourable. The situation is quite different with $\mathbf{2 b}$, since the stabilization is only due to favourable entropy terms, which are more or less constant $(73.4-$ $71 \mathrm{~kJ} \mathrm{~mol}^{-1}$ ) with the first three cations and increases to $81.7 \mathrm{~kJ} \mathrm{~mol}^{-1}$ with $\mathrm{Gd}^{3+}$. In contrast, the enthalpy contribution is positive and hence unfavourable, especially with $\mathrm{Gd}^{3+}(\Delta H=50.8$ $\mathrm{kJ} \mathrm{mol}^{-1}$ ). In fact, with both ligands, the entropic terms are always positive and favourable. 
This is certainly due to the importance of the solvation of the lanthanides. Another factor, which cannot be neglected, is the ligand solvation. With $\mathbf{2} \mathbf{b}$, possessing in its macrocyclic skeleton three ethereal oxygen atoms, solvation is expected to be stronger than with $\mathbf{1 b}$. This can explain, at least partly, both the low enthalpy and the high entropy terms observed with the former ligand. In the absence of reliable data in methanol for the calix[4]arene counterpart $\mathbf{3 b}$, these results can be compared to previous data concerning the complexation of alkaline earth cations by $\mathbf{3 b}$ in the same solvent. With these systems involving multicharged cations, the complexation process was also entropically controlled (31).

Changing the counter ion from triflate to nitrate has also an influence on $\Delta H$ and $T \Delta S$, as seen for the complexation of lanthanum with $\mathbf{1 b}$ and $\mathbf{2 b}$, which is characterized by slightly more favourable or less unfavourable enthalpic terms and to less positive entropic contributions. These results are consistent with the nitrate anions still interacting with the cation in the complexes.

\section{Proton NMR studies}

To obtain further information on the cation binding behaviour of diethylamides $\mathbf{1 b}, \mathbf{2} \mathbf{b}$ and 3b, specifically concerning the binding sites, proton NMR titrations were performed in $\mathrm{CDCl}_{3} / \mathrm{CD}_{3} \mathrm{OD}$. The cations studied were $\mathrm{La}^{3+}, \mathrm{Eu}^{3+}$ and $\mathrm{Yb}^{3+}$. Variable amounts of the salts were added to the ligands and the proton spectra recorded after each addition.

Different situations were found after the addition of the salts to the ligands. The three amides exhibit similar behaviours towards $\mathrm{La}^{3+}$. These titrations show that with [salt]/[ligand] ratios lower than one, both signals of the complexed and uncomplexed ligands are present in the spectra, indicating that on the NMR time scale the exchange rate between the two species is slow at room temperature. This behaviour reflects the high affinity of these ligands towards 
$\mathrm{La}^{3+}$ as previously observed. Upon reaching 1:1 ratios, all the signals for the free ligands disappear and those of the complexed ligands remain unaltered after subsequent addition of the salt, indicating a 1:1 metal-to-ligand stoichiometry. In the case of ligand $\mathbf{1 b}$, besides the 1:1 complex, another set of sharp signals with lower intensity can be seen in the spectra, from the addition of the first aliquot of salt (Figure 5). This possibly reflects a 1:2 metal-to-ligand stoichiometry for the second complex (B), since the intensity of B peaks decreases as the addition of the salt proceeds. Similar situations have already been observed by us before (32, 33). In order to confirm the stoichiometry of these complexes, a Job plot based on ${ }^{1} \mathrm{H}$ NMR data was carried out. The Job plot shown in Figure 6 clearly confirms the formation of a 1:1 metal-to-ligand complex, but no unambiguous stoichiometry can be established from the curve for the weaker complex (B), due to the predominance of complex A (34). Complex B shows a plateau rather than a maximum between 0.5 and 0.6 mole fraction of $\mathbf{1 b}$, the same situation found by us before with two ketone derivative analogues and $\mathrm{Ca}^{2+}$ and $\mathrm{Sr}^{2+}$ cations. In contrast, titrations of diethylamides $\mathbf{1 b}, \mathbf{2} \mathbf{b}$ and $\mathbf{3 b}$ with $\mathrm{Eu}^{3+}$ and mainly $\mathrm{Yb}^{3+}$ produce broad and distorted proton signals, which are shifted toward high and low fields. This behaviour is more evident for derivatives $\mathbf{1 b}$ and $\mathbf{3 b}$, and the shifts observed cover a range greater than $20 \mathrm{ppm}$. This is consistent with the knowledge that the binding of paramagnetic metal ions, such as $\mathrm{Eu}^{3+}$ and $\mathrm{Yb}^{3+}$, causes enhanced shift and relaxation effects on the resonances of the nuclei of the ligands $(6 c)$. The results indicate that complexation occurs between the ligands and these cations, and are in agreement with those obtained by spectrophotometry / potentiometry in the present study.

Proton NMR data of the free and complexed ligands are collected in Table 4. The complete interpretation of the spectrum for compound $\mathbf{1 b}$ required an additional COSY spectrum. However, in the case of the weaker complex (B), full proton assignment was not possible due to overlapping of signals arising from both complexed species. Complexation of 
$\mathrm{La}^{3+}$ affects all the proton chemical shifts in ligands $\mathbf{1 b}, \mathbf{2} \mathbf{b}$ and $\mathbf{3 b}$. In the case of $\mathrm{Eu}^{3+}$ and $\mathrm{Yb}^{3+}$ the broad and distorted signals obtained, as already mentioned, prevented a quantitative analysis of the data.

The largest chemical shift changes are recorded for the bridging axial methylene protons $\left(\mathrm{ArCH} \mathrm{H}_{2} \mathrm{Ar}\right)$ and the oxygen bridge equatorial methylene protons $\left(\mathrm{CH}_{2} \mathrm{OCH}_{2}\right)$, in the case of $\mathbf{2 b}$, which move upfield, and by the aromatic protons and the methylene protons of the $\mathrm{OCH}_{2} \mathrm{CO}$ groups, which move downfield. As observed for other calixarenes, the variation in chemical shift experienced by the equatorial methylene protons $\left(\mathrm{ArCH}_{2} \mathrm{Ar}\right)$ is downfield and smaller than that of the axial protons, but in the present case it is still very high $(\Delta \delta=0.52$ and $0.53 \mathrm{ppm}$ for $\mathbf{1 b}$ and $0.60 \mathrm{ppm}$ for $\mathbf{3 b}$ ). The $\mathrm{CH}_{2} \mathrm{OCH}_{2}$ resonances behave differently, as previously reported (21-23). The equatorial methylene protons of the oxygen bridge move upfield and experience larger shift variations than the axial ones. These results suggest that the oxygen bridge conformation changes significantly upon complexation, with the equatorial protons undergoing a higher shielding effect. The smallest variations are observed for the protons of the $\mathrm{N}\left(\mathrm{CH}_{2} \mathrm{CH}_{3}\right)_{2}$ and tert-butyl groups.

A closer examination of the spectral changes upon complexation indicates that the differences in the chemical shifts between the axial and the equatorial protons of the $\mathrm{ArCH}_{2} \mathrm{Ar}$ bridges in ligands $\mathbf{1 b}$ and $\mathbf{3 b}(\Delta \delta=1.64,1.77 \mathrm{ppm}$ for $\mathbf{1 b}$ and $2.10 \mathrm{ppm}$ for $\mathbf{3 b})$ decrease $(\Delta \delta$ $=0.46,0.39 \mathrm{ppm}$ for $\mathbf{1 b}$ and $0.51 \mathrm{ppm}$ for $\mathbf{3 b}$ ), being closer to $0.5 \mathrm{ppm}$ (35). This suggests that the free ligands depart from a distorted cone conformation and adopt a flattened cone conformation after complexation, with their pendant arms moving closer together. If Gutsche's criterion is also applicable to the $\mathrm{CH}_{2} \mathrm{OCH}_{2}$ bridges, it indicates that ligand $\mathbf{2 b}$ is much more flattened $(\Delta \delta=0.32 \mathrm{ppm})$ than $\mathbf{1 b}$ and $\mathbf{3 b}$, and stands up when the cation enters into the ionophoric cavity $(\Delta \delta=0.74 \mathrm{ppm})$. 


\section{Conclusions}

Extraction studies from an aqueous solution into $\mathrm{CH}_{2} \mathrm{Cl}_{2}$ and stability constant measurements in methanol have shown that diethylamide $\mathbf{1 b}$ is a very strong binder for lanthanides, showing high extraction percentages and the highest stability constant values ever found with this ligand $(\log \beta=8.6-9.2)$. It displays some preference for the light lanthanides (from $\mathrm{La}^{3+}$ to $\mathrm{Eu}^{3+}$ ) in extraction, but it does not noticeably discriminate between them (from $\mathrm{La}^{3+}$ to $\mathrm{Yb}^{3+}$ ) in complexation. In the case of diethylamide $\mathbf{2 b}$, the data showed that it is a weaker extractant and exhibits lower $\log \beta$ values, but it is a more selective ligand, showing clearly a positive discrimination for the light lanthanides. The weaker binding power of $\mathbf{2} \mathbf{b}$ may be due to its lack of donating sites compared to $\mathbf{1 b}$, as lanthanide cations require high coordination numbers. Diethylamide $\mathbf{3 b}$ exhibits a similar behaviour to that of its analogous $\mathbf{1} \mathbf{b}$, at least in complexation. With $\mathbf{1 b}$ the complexation process of all the cations is enthalpically and entropically stabilised, since the enthalpy changes are clearly negative, while the entropy changes are positive. In contrast, the complexation process with $\mathbf{2} \mathbf{b}$ is governed by the entropy changes only. Proton NMR titrations corroborated the formation of 1:1 complexes between all the amides and $\mathrm{La}^{3+}$ cation, also indicating that the cation should be encapsulated into the 
cavity defined by the phenoxy and the carbonyl oxygen atoms. In the case of complexation of 1b with $\mathrm{La}^{3+}$, besides the 1:1 complex, minor amounts of another complex with a different ligand-to-metal stoichiometry was formed.

\section{Experimental}

\section{Extraction studies}

Equal volumes $(5 \mathrm{~mL})$ of aqueous solutions of metal picrates $\left(2.5 \times 10^{-4} \mathrm{M}\right)$ and solutions of the calixarenes $\left(2.5 \times 10^{-4} \mathrm{M}\right)$ in $\mathrm{CH}_{2} \mathrm{Cl}_{2}$ were vigorously shaken for 2 min, and then thermostated in a water bath with mechanical stirring at $20{ }^{\circ} \mathrm{C}$ overnight. After complete phase separation, the concentration of picrate ion in the aqueous phase was determined spectrophotometrically $\left(\lambda_{\max }=354 \mathrm{~nm}\right)$. For each cation-calixarene system the absorbance measurements were repeated at least four times. Blank experiments showed negligible picrate extraction in the absence of a calixarene. The details of the metal picrate preparation have already been described (23).

\section{Determination of stability constants}

UV absorption spectrophotometric titrations were carried out to obtain the stability constants $(\log \beta)$ of the complexes formed between the lanthanide chlorides (and in some cases lanthanide nitrates) and the two ligands $\mathbf{1 b}$ and $\mathbf{2 b}$. All the experiments were performed in methanol at $25{ }^{\circ} \mathrm{C}$ in the presence of $\mathrm{Et}_{4} \mathrm{NCl}$ as the supporting electrolyte. The detail of the procedure has been published previously (28). The ligand concentrations were in the range $6.4 \times 10^{-5}-5.7 \times 10^{-4} \mathrm{M}$ and the final cation to ligand concentration ratios were in the range $1.5-10$, depending on the strength of the complexes. The measurements were treated by the 
program Specfit (37) to give the stoichiometry and the stability constants of the complexes. For very stable complexes $(\log \beta \geq 7)$, i.e. with ligands $\mathbf{1 b}$ and $\mathbf{3 b}$, potentiometric titrations based on a competition with $\mathrm{Ag}^{+}$as auxiliary cation, were performed as already described (28). The $\mathrm{Ag}^{+}$concentration was typically around $7.5 \times 10^{-4} \mathrm{M}$. Similar lanthanide concentrations were used except for $\mathrm{Yb}^{3+}$ solutions, which were about $1.6 \times 10^{-4} \mathrm{M}$. The data were treated using the program SIRKO (38).

The lanthanide (lanthanum, praseodymium, europium, gadolinium and ytterbium) salts used for spectrophotometric measurements were chlorides and in some cases (lanthanum, europium and ytterbium) also nitrates. They were all purchased from Alfa Aesar (99.99 \%). Tetraethylammonium chloride (Fluka, purum, $\geq 98 \%$ ) and nitrate (Acros Organics, $99 \%$ ) supporting electrolyte were used without further purification. The metal salts used for potentiometric measurements were the lanthanide and silver trifluoromethanesulfonates (Alfa Aesar, min $98 \%$ ). In these cases, tetraethylammmonium perchlorate (Fluka, purum, $\geq 99 \%$ ) was used as the supporting electrolyte. All these salts were dried under vacuum at ambient temperature during 48 hours before use. The concentration of the lanthanide stock solutions (ca. $10^{-2} \mathrm{M}$ ) was standardized by complexometry with EDTA using xylenol orange as coloured indicator (39). The concentration of $\mathrm{Ag}^{+}$solutions was determined by potentiometry with addition of $\mathrm{NaCl}$. Methanol (Sigma Aldrich, Chromasolv, water content max $0.03 \%$ ) was used without further purification.

\section{Microcalorimetric titrations}

Microcalorimetric experiments were performed using a 2277 Thermal Activity Monitor Microcalorimeter (Thermometric). Titrations were carried out at $25{ }^{\circ} \mathrm{C}$ on $2.5 \mathrm{~mL}$ of the ligand solution in methanol of concentrations ranging from $8.0 \times 10^{-5}$ to $4.0 \times 10^{-3} \mathrm{M}$, using a 
$4 \mathrm{~mL}$ glass cell. The heats of complexation were measured after addition of $17 \times 15 \mu \mathrm{L}$ aliquots of $c a .6 .0 \times 10^{-3} \mathrm{M}$ lanthanide triflate solutions or $c a .5 .0 \times 10^{-2} \mathrm{M}$ lanthanum nitrate solutions in the same solvent and then corrected for the heat of dilution of the metal salt determined in separate titrations without the ligands. Chemical calibration of the calorimeter was made by determination of the complexation enthalpy of $\mathrm{Rb}^{+}$with $18 \mathrm{C} 6$ in methanol as recommended (40). With ligands $\mathbf{1 b}$ and $\mathbf{3 b}$, the stability constants $(\log \beta \geq 7)$ were high enough to consider that the complexes formed completely after each addition of metal ion. In this cases, the complexation enthalpy, $\Delta H$, was obtained from the slope of the linear plots of the corrected cumulated heats exchanged versus the number of moles of metal added until the 1:1 stoichiometry. With ligand $\mathbf{2} \mathbf{b}$, which forms less stable complexes with all the cations studied except $\mathrm{La}^{3+}, \log \beta$ and $\Delta H$ were calculated simultaneously using the program DIGITAM version 4.1 (41). The corresponding complexation entropies were then calculated from the equations $\Delta G=\Delta H-T \Delta S$ and $\Delta G=-\mathrm{R} T \ln \beta$, knowing $\beta$ from spectrophotometry.

\section{Proton NMR experiments}

Several aliquots (up to $2-3$ equiv) of the salt solutions $(0.25 \mathrm{M})$ in $\mathrm{CD}_{3} \mathrm{OD}$ were added to $\mathrm{CDCl}_{3}$ solutions $\left(5 \times 10^{-3} \mathrm{M}\right)$ of the ligands directly in the NMR tube. The salts used were La, $\mathrm{Eu}$ and $\mathrm{Yb}$ triflates. Due to the low solubility of $\mathrm{Eu}$ triflate in $\mathrm{MeOH}$, it was necessary to decrease the concentration of the ligand $\left(2.5 \times 10^{-4} \mathrm{M}\right)$ and of the salt $\left(4.17 \times 10^{-3} \mathrm{M}\right)$. The spectra were recorded on a Bruker Avance III 500 Spectrometer after each addition of the salts. The temperature of the NMR probe was kept constant at $22{ }^{\circ} \mathrm{C}$. Job's method was performed for diethylamide $\mathbf{1 b}$ and La triflate. The total concentration was maintained at $1 \times$ $10^{-2} \mathrm{M}$ in $\mathrm{CDCl}_{3}-\mathrm{CD}_{3} \mathrm{OD}(9: 1)$. The COSY spectrum was the result of 32 transients per increment, in a total of 256. 


\section{References}

(1) Gutsche, C.D. In Calixarenes Revisited; Stoddart, J.F., Ed.; The Royal Society of Chemistry: Cambridge, 1998.

(2) Mandolini, L.; Ungaro, R.; Eds.; Calixarenes in Action; Imperial College Press: London, 2000.

(3) Asfari, Z.; Böhmer, V.; Harrowfield, J.; Vicens, J.; Eds.; Calixarenes 2001; Kluwer Academic Publishers: Dordrecht, 2001.

(4) (a) McKervey, M.A.; Schwing-Weill, M.J.; F. Arnaud-Neu, F. In Comprehensive Supramolecular Chemistry; Lehn, J.M., Gokel, G.W., Eds.; Elsevier: Oxford, 1996; pp 537-603. (b) Arnaud-Neu, F.; McKervey, M.A.; Schwing-Weill, M.J. In Calixarenes 2001; Asfari, Z., Böhmer, V., Harrowfield, J., Vicens, J., Eds.; Kluwer Academic Publishers: Dordrecht, 2001; pp 385-406.

(5) Roundhill, D.M.; Shen, J.Y. In Calixarenes 2001, Asfari, Z., Böhmer, V., Harrowfield, J., Vicens, J., Eds.; Kluwer Academic Publishers: Dordrecht, 2001; pp 407-420.

(6) (a) Böhmer, V. In Calixarenes for Separations. ACS Symposium series 757; Lumetta, G.J., Rogers, R.D., Gopalan, A.S., Eds.; American Chemical Society: Washington, 2000; pp 135-149. (b) Arnaud-Neu, F.; Barboso, S.; Byrne, D.; Charbonnière, L.J.; SchwingWeill, M.J.; Ulrich, G. In Calixarenes for Separations. ACS Symposium series 757; Lumetta, G.J., Rogers, R.D., Gopalan, A.S., Eds.; American Chemical Society: Washington, 2000; pp 150-164. (c) Lambert, B.; Jacques, V.; Desreux, J.F. In Calixarenes for Separations. ACS Symposium series 757; Lumetta, G.J., Rogers, R.D., Gopalan, A.S., Eds.; American Chemical Society: Washington, 2000; pp 165-178. (d) Bünzli, J.-C.G.; Besançon, F.; Ihringer, F. In Calixarenes for Separations. ACS Symposium series 757; Lumetta, G.J., Rogers, R.D., Gopalan, A.S., Eds.; American Chemical Society: Washington, 2000; pp 179-194. 
(7) (a) Arnaud-Neu, F.; Schwing-Weill, M.J.; Dozol, J.-F. In Calixarenes 2001; Asfari, Z., Böhmer, V., Harrowfield, J., Vicens, J., Eds.; Kluwer Academic Publishers: Dordrecht, 2001; pp 642-662. (b) Arnaud-Neu, A. Radiochim. Acta 2003, 91, 659-664.

(8) Pearson, R.G. Science 1966, 151, 172-177.

(9) Mikulasek, L.; Grüner, B.; Dordea, C.; Rudzevich, V.; Böhmer, V.; Haddaoui, J.; Hubscher-Bruder, V.; Arnaud-Neu, F.; Caslavsky, J.; Selucky, P. Eur. J. Org. Chem. 2007, 4772-4783.

(10) Herschbach, H.; Brisach, F.; Haddaoui, J.; Saadioui, M.; Leize, E.; Van Dorsselaer, A.; Arnaud-Neu, F.; Böhmer, V. Talanta 2007, 74, 39-46.

(11) Arnaud-Neu, F.; Browne, J.K.; Byrne, D.; Marrs, D.J.; McKervey, M.A.; O’Hagan, P.; Schwing-Weill, M.J.; Walker, A. Chem. Eur. J. 1999, 5, 175-186.

(12) Karavan, M.; Arnaud-Neu, F.; Hubscher-Bruder, V.; Smirnov, I.; Kalchenko, V. J. Incl. Phenom. Macrocycl. Chem. 2010, 66, 113-123.

(13) Arnaud-Neu, F.; Cremin, S.; Harris, S.; McKervey, M.A.; Schwing-Weill, M.J.; Schwinté, P.; Walker, A. J. Chem. Soc., Dalton Trans. 1997, 329-334.

(14) Aime, S.; Barge, A.; Botta, M.; Casnati, A.; Fragai, M.; Luchinat, C.; Ungaro, R. Angew. Chem. Int. Ed. 2001, 40, 4737-4739.

(15) Beer, P.D.; Brindley, G.D.; Fox, O.D.; Grieve, A.; Ogden, M.I.; Szemes, F.; Drew, M.G.B. J. Chem. Soc., Dalton Trans. 2002, 3101-3111.

(16) Danil de Namor, A.F.; Jafou, O. J. Phys. Chem. B 2001, 105, 8018-8027.

(17) Danil de Namor, A.F.; Baron, K.; Chahine, S.; Jafou, O. J. Phys. Chem. A 2004, 108, 1082-1089.

(18) Casnati, A.; Della Ca, N.; Fontanella, M.; Sansone, F.; Ugozzoli, F.; Ungaro, R.; Liger, K.; Dozol, J.-F. Eur. J. Org. Chem. 2005, 2338-2348. 
(19) Casnati, A.; Barboso, S.; Rouquette, H.; Schwing-Weill, M.J.; Arnaud-Neu, F.; Dozol, J.-F.; Ungaro, R. J. Am. Chem. Soc. 2001, 123, 12182-12190.

(20) Sansone, F.; Fontanella, M.; Casnati, A.; Ungaro, R.; Böhmer, V.; Saadioui, M.; Liger, K.; Dozol, J.-F. Tetrahedron 2006, 62, 6749-6753.

(21) Marcos, P.M.; Félix, S.; Ascenso, J.R.; Segurado, M.A.P.; Pereira, J.L.C.; KhazaeliParsa, P.; Hubscher-Bruder, V.; Arnaud-Neu, F. New J. Chem. 2004, 28, 748-755.

(22) Marcos, P.M.; Ascenso, J.R.; Cragg, P.J. Supramol. Chem. 2007, 19, 199-206.

(23) Marcos, P. M.; Ascenso, J.R.; Segurado, M.A.P.; Bernardino, R.J.; Cragg, P.J. Tetrahedron 2009, 65, 496-503.

(24) Félix, S.; Ascenso, J.R.; Lamartine, R.; Pereira, J.L.C. Tetrahedron 1999, 55, 85398546.

(25) (a) Matsumoto, T.; Nishio, S.; Takeshita, M.; Shinkai, S. Tetrahedron 1995, 51, 46474654. (b) Cragg, P.J.; Drew, M.G.B.; Steed, J.W. Supramol. Chem. 1999, 11, 5-15.

(26) Arduini, A.; Ghidini, E.; Pochini, A.; Ungaro, R.; Andreetti, G.D.; Calestani, G.; Ugozzoli, F. J. Inclusion Phenom. 1988, 6, 119-134.

(27) Pedersen, C. J. Am. Chem. Soc. 1970, 92, 391-394.

(28) Arnaud-Neu, F.; Schwing-Weill, M.J.; Ziat, K.; Cremin, S.; Harris, S.J.; McKervey, M.A. New. J. Chem. 1991, 15, 33-37.

(29) Bünzli, J.-C.G.; Merbach, A.E.; Nielson, R.M. Inorg. Chim. Acta 1987, 139, 151-152.

(30) Martell, A.E.; Smith, R.M. In Critical Stability Constants, vol. 1: Amino acids, Plenum Press: New York, 1974.

(31) Arnaud-Neu, F.; Barrett, G.; Fanni, S.; Marrs, D.; McGregor, W.; McKervey, M.A.; Schwing-Weill, M.J.; Vetrogon, V.; Wechsler, S. J. Chem. Soc., Perkin Trans. 2 1995, 453-461. 
(32) Marcos, P.M.; Félix, S.; Ascenso, J.R.; Segurado, M.A.P.; Mellah, B.; Abidi, R.; Hubscher-Bruder, V.; Arnaud-Neu, F. Supramol. Chem. 2006, 18, 285-297.

(33) Marcos, P.M.; Ascenso, J.R. Tetrahedron 2006, 62, 3081-3088.

(34) Caldeira, M.M.; Ramos, M.L.; Oliveira, N.C.; Gil, V.M.S. Can. J. Chem. 1987, 65, 2434-2440.

(35) Gutsche, C.D. In Calixarenes, The Royal Society of Chemistry: Cambridge, 1989.

(36) Arduini, A.; Pochini, A.; Reverberi, S.; Ungaro, R.; Andreetti, G.; Ugozzoli, F. Tetrahedron 1986, 42, 2089-2100.

(37) Gampp, H.; Maeder, M.; Meyer, C.J.; Zuberbuehler, A.D. Talanta 1985, 32, 257-264.

(38) Vetrogon, V.I.; Lukyanienko, N.G.; Schwing-Weill, M.J.; Arnaud-Neu, F. Talanta 1994, 41, 2105-2112.

(39) Méthodes d'Analyse Complexométriques avec le Titriplex; Merck, E., Ed.; 3rd edn, Grafis: Darmstadt, 1992.

(40) Arnaud-Neu, F.; Delgado, R.; Chaves, S. Pure Appl. Chem. 2003, 75, 71-102.

(41) Hallen, D. Pure Appl. Chem. 1993, 65, 1527-1532. 
Table 1. Percentage extraction of lanthanide picrates into $\mathrm{CH}_{2} \mathrm{Cl}_{2}$ at $20{ }^{\circ} \mathrm{C}^{\mathrm{a}}$

$\mathrm{La}^{3+} \quad \mathrm{Ce}^{3+} \quad \mathrm{Pr}^{3+} \quad \mathrm{Nd}^{3+} \quad \mathrm{Sm}^{3+} \quad \mathrm{Eu}^{3+} \quad \mathrm{Gd}^{3+} \quad \mathrm{Dy}^{3+} \quad \mathrm{Er}^{3+} \quad \mathrm{Yb}^{3+}$

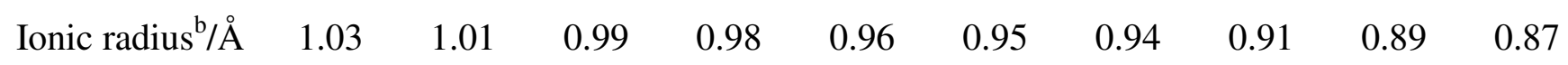

$1 b$

71
$74 \quad 76 \quad 75$

$69 \quad 75$

47

$67 \quad 57$

$2 b$

$28 \quad 34$

$34 \quad 34$

$31 \quad 30$

$17 \quad 18$

13

3b

$\begin{array}{lll}12 & 14 & 17\end{array}$

\section{9}

23

24

20

\footnotetext{
${ }^{a}$ Values with uncertainties less than $5 \%$.
}

${ }^{\mathrm{b}}$ Shannon, R. D.; Prewitt, C.T. Acta Cryst. 1969, B25, 925; 1970, B26, 1046; data quoted in Marcus, I. Ion Properties, Marcel Dekker: New York, 1997, pp 46-47. 
Table 2. Logarithms of the stability constants $\left(\log \beta \pm \sigma_{\mathrm{n}-1}\right)^{\mathrm{a}}$ of lanthanide complexes with $\mathbf{1 b}$, 2b and 3b (Methanol, $I=0.01 \mathrm{M}^{\text {in }} \mathrm{Et}_{4} \mathrm{NCl}, \mathrm{Et}_{4} \mathrm{NNO}_{3}$ or $\mathrm{Et}_{4} \mathrm{NClO}_{4}, T=25^{\circ} \mathrm{C}$ )

\begin{tabular}{|c|c|c|c|c|c|c|}
\hline Ligand & Method/medium & $\mathrm{La}^{3+}$ & $\operatorname{Pr}^{3+}$ & $\mathrm{Eu}^{3+}$ & $\mathrm{Gd}^{3+}$ & $\mathrm{Yb}^{3+}$ \\
\hline \multirow[t]{3}{*}{$1 b$} & Spec. / $\mathrm{Cl}^{-}$ & $\geq 7$ & $\geq 7$ & $\geq 7$ & $\geq 7$ & $\geq 7$ \\
\hline & Spec. $/ \mathrm{NO}_{3}{ }^{-}$ & $6.2 \pm 0.3$ & - & $6.1 \pm 0.2$ & - & $5.5 \pm 0.2$ \\
\hline & Pot. $/ \mathrm{ClO}_{4}^{-}$ & $8.88 \pm 0.08$ & $9.2 \pm 0.3$ & $8.87 \pm 0.01$ & $9.0 \pm 0.1$ & $8.6 \pm 0.2$ \\
\hline \multirow[t]{2}{*}{$2 b$} & Spec. / $\mathrm{Cl}^{-}$ & $5.5 \pm 0.2$ & $4.9 \pm 0.1$ & $4.7 \pm 0.4$ & $4.3 \pm 0.3$ & $3.4 \pm 0.1$ \\
\hline & Spec. / $\mathrm{NO}_{3}{ }^{-}$ & $2.2 \pm 0.6$ & - & $2.08 \pm 0.04$ & - & $\leq 2$ \\
\hline $\mathbf{3 b}$ & Pot. / $\mathrm{ClO}_{4}^{-}$ & $8.86 \pm 0.07$ & $8.5 \pm 0.7$ & $8.9 \pm 0.1$ & $8.9 \pm 0.2$ & $8.2 \pm 0.4$ \\
\hline
\end{tabular}

${ }^{\mathrm{a}}$ Standard deviation $\sigma_{\mathrm{n}-1}$ on the mean of several experiments. 
Table 3. Complexation thermodynamic parameters of lanthanide triflates with $\mathbf{1 b}, \mathbf{2} \mathbf{b}$ and $\mathbf{3 b}$ obtained by microcalorimetric titrations (Methanol, $T=25^{\circ} \mathrm{C}$ )

\begin{tabular}{|c|c|c|c|c|c|}
\hline Ligand & Parameter & $\mathrm{La}^{3+}$ & $\operatorname{Pr}^{3+}$ & $\mathrm{Eu}^{3+}$ & $\mathrm{Gd}^{3+}$ \\
\hline \multirow[t]{4}{*}{$1 b$} & $\log \beta$ & $\begin{array}{c}8.88 \pm 0.08 \\
(6.55)^{\mathrm{a}}\end{array}$ & $9.2 \pm 0.3$ & $8.87 \pm 0.01$ & $9.0 \pm 0.1$ \\
\hline & $-\Delta G\left(\mathrm{~kJ} \mathrm{~mol}^{-1}\right)$ & $\begin{array}{l}50.6 \pm 0.4 \\
(37.34)^{\mathrm{a}}\end{array}$ & $52 \pm 2$ & $50.56 \pm 0.06$ & $51.3 \pm 0.6$ \\
\hline & $-\Delta H\left(\mathrm{~kJ} \mathrm{~mol}^{-1}\right)$ & $\begin{array}{c}26.34 \pm 0.07 \\
(27.22)^{\mathrm{a}}\end{array}$ & $31.77 \pm 0.07$ & $24.78 \pm 0.01$ & $28 \pm 1$ \\
\hline & $T \Delta S\left(\mathrm{~kJ} \mathrm{~mol}^{-1}\right)$ & $\begin{array}{l}24.3 \pm 0.5 \\
(10.12)^{\mathrm{a}}\end{array}$ & $21 \pm 2$ & $25.78 \pm 0.07$ & $23 \pm 2$ \\
\hline \multirow[t]{4}{*}{$2 \mathbf{b}$} & $\log \beta$ & $\begin{array}{c}6.05 \pm 0.04 \\
(3.0 \pm 0.04)^{\mathrm{a}}\end{array}$ & $6.31 \pm 0.05$ & $6.0 \pm 0.1$ & $5.43 \pm 0.03$ \\
\hline & $-\Delta G\left(\mathrm{~kJ} \mathrm{~mol}^{-1}\right)$ & $\begin{array}{c}34.5 \pm 0.2 \\
(17.1 \pm 0.2)^{\mathrm{a}}\end{array}$ & $35.9 \pm 0.3$ & $34.2 \pm 0.6$ & $30.9 \pm 0.2$ \\
\hline & $-\Delta H\left(\mathrm{~kJ} \mathrm{~mol}^{-1}\right)$ & $\begin{array}{c}-38.9 \pm 0.4 \\
(-17.7 \pm 0.5)^{\mathrm{a}}\end{array}$ & $-35 \pm 2$ & $-38.5 \pm 0.4$ & $-50.8 \pm 0.4$ \\
\hline & $T \Delta S\left(\mathrm{~kJ} \mathrm{~mol}^{-1}\right)$ & $\begin{array}{c}73.4 \pm 0.6 \\
(34.8 \pm 0.7)^{\mathrm{a}}\end{array}$ & $71 \pm 2$ & $73 \pm 1$ & $81.7 \pm 0.6$ \\
\hline
\end{tabular}

${ }^{\text {a }}$ Titration with $\mathrm{La}\left(\mathrm{NO}_{3}\right)_{3}$ 
Table 4. Relevant proton chemical shifts ( $\delta$, ppm) of ligands $\mathbf{1 b}, \mathbf{2} \mathbf{b}$ and $\mathbf{3 b}$ and its metal complexes

\begin{tabular}{|c|c|c|c|c|c|c|c|}
\hline & \multirow[t]{2}{*}{$t-\mathrm{Bu}$} & \multicolumn{2}{|c|}{$\mathrm{ArCH}_{2} \mathrm{Ar}$} & \multicolumn{2}{|c|}{$\mathrm{CH}_{2} \mathrm{OCH}_{2}$} & \multirow[t]{2}{*}{$\mathrm{OCH}_{2} \mathrm{CO}$} & \multirow[t]{2}{*}{$\mathrm{ArH}$} \\
\hline & & eq & ax & eq & $\mathrm{ax}$ & & \\
\hline $1 b$ & $0.95,1.17$ & $3.27,3.31$ & $4.91,5.08$ & 4.67 & 4.89 & $4.36,4.78,4.90,5.04$ & $6.72,6.90,6.99,7.02$ \\
\hline $\mathbf{1 b}+\mathrm{La}^{3+}(\mathrm{A})$ & $1.18,1.26$ & $3.80,3.83$ & $4.26,4.22$ & 4.36 & 4.94 & $4.97,5.04,5.46,5.49$ & $7.20,7.41,7.45,7.64$ \\
\hline $\mathbf{1 b}+\mathrm{La}^{3+}(\mathrm{B})$ & $1.23,1.26$ & $\mathrm{a}$ & a & 4.33 & 4.90 & a & $7.17,7.37,7.41,7.58$ \\
\hline $2 b$ & 1.08 & & & 4.62 & 4.94 & 4.57 & 6.98 \\
\hline $\mathbf{2 b}+\mathrm{La}^{3+}$ & 1.15 & & & 4.36 & 5.10 & 4.75 & 7.02 \\
\hline $3 \mathbf{b}$ & 1.07 & 3.19 & 5.29 & & - & 5.02 & 6.78 \\
\hline $\mathbf{3 b}+\mathrm{La}^{3+}$ & 1.19 & 3.79 & 4.30 & & - & 5.34 & 7.34 \\
\hline
\end{tabular}

${ }^{\mathrm{a}}$ Not possible to assign 
Figure 1. Structural formulae of calixarenes.

Figure 2. Spectrophotometric titration of $\mathbf{1 b}\left(C_{\mathbf{1 b}}=3.67 \times 10^{-4} \mathrm{M}\right)$ with $\operatorname{PrCl}_{3}\left(0 \leq C_{\mathrm{Pr}} / C_{\mathbf{1 b}} \leq\right.$ 1.24) in methanol at $25^{\circ} \mathrm{C}$.

Figure 3. Microcalorimetric titration of $2.5 \mathrm{~mL}$ of $\mathbf{1 b}\left(4.43 \times 10^{-4} \mathrm{M}\right)$ by addition of $17 \times 15$ $\mu \mathrm{L}$ of $6.25 \times 10^{-3} \mathrm{M}$ of $\mathrm{Gd}\left(\mathrm{CF}_{3} \mathrm{SO}_{3}\right)_{3}$ in methanol at $25^{\circ} \mathrm{C}$.

Figure 4. Microcalorimetric titration of $2.5 \mathrm{~mL}$ of $2 \mathbf{b}\left(4.56 \times 10^{-4} \mathrm{M}\right)$ by addition of $17 \times 15$ $\mu \mathrm{L}$ of $6.25 \times 10^{-3} \mathrm{M}$ of $\mathrm{Gd}\left(\mathrm{CF}_{3} \mathrm{SO}_{3}\right)_{3}$ in methanol at $25^{\circ} \mathrm{C}$.

Figure 5. Aromatic region of the ${ }^{1} \mathrm{H}$ NMR spectra of $\mathbf{1 b}$ in $\mathrm{CDCl}_{3} / \mathrm{CD}_{3} \mathrm{OD}, 22{ }^{\circ} \mathrm{C}$ and 500 MHz. (a) free ligand, (b) upon addition of 0.5 , (c) 1 equiv and (d) 3 equivs. of $\mathrm{La}\left(\mathrm{CF}_{3} \mathrm{SO}_{3}\right)_{3}$.

Figure 6. Job's plot based on ${ }^{1} \mathrm{H}$ NMR data for the system $\mathbf{1 b}+\mathrm{La}^{3+}$; total concentration $1 \times$ $10^{-2} \mathrm{M}$ in $\mathrm{CDCl}_{3}-\mathrm{CD}_{3} \mathrm{OD}(9: 1, \mathrm{v} / \mathrm{v})$. 


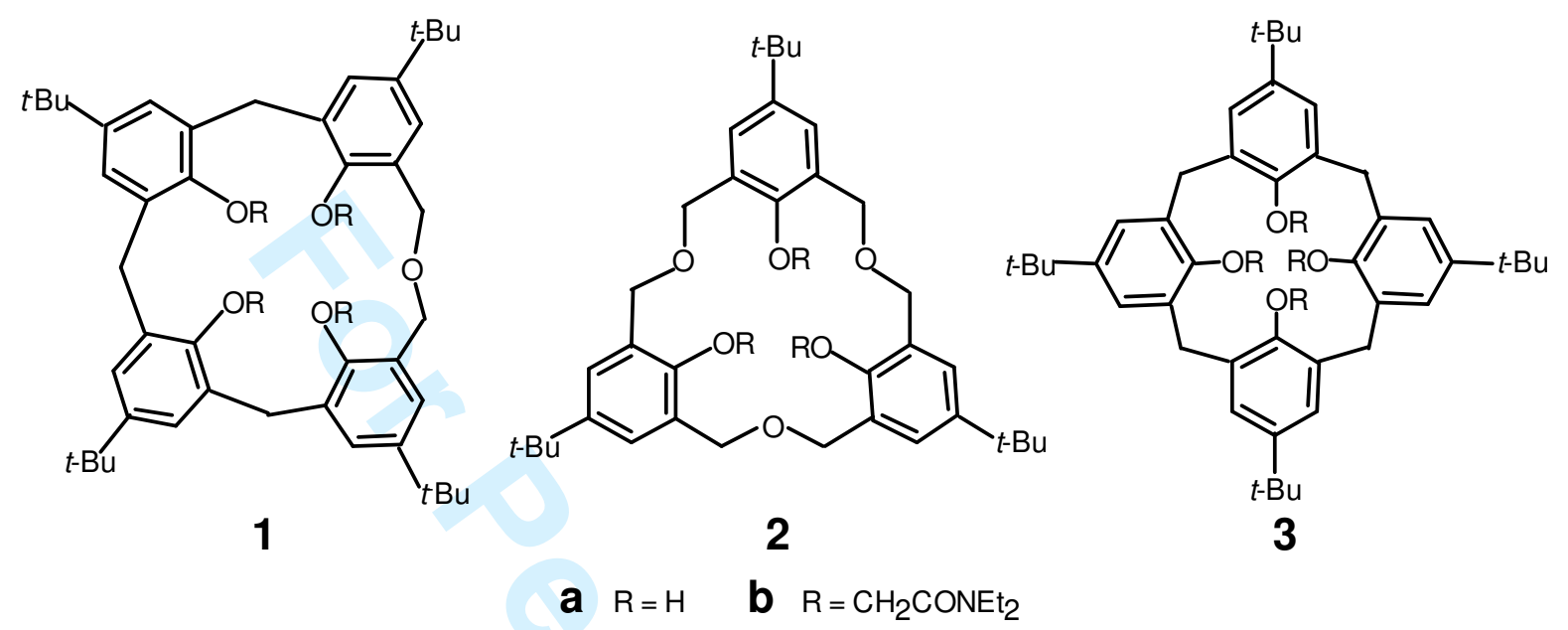

\section{Figure 1}

URL: http:/mc.manuscriptcentral.com/tandf/gsch Email: suprachem@mail.cm.utexas.edu 26 


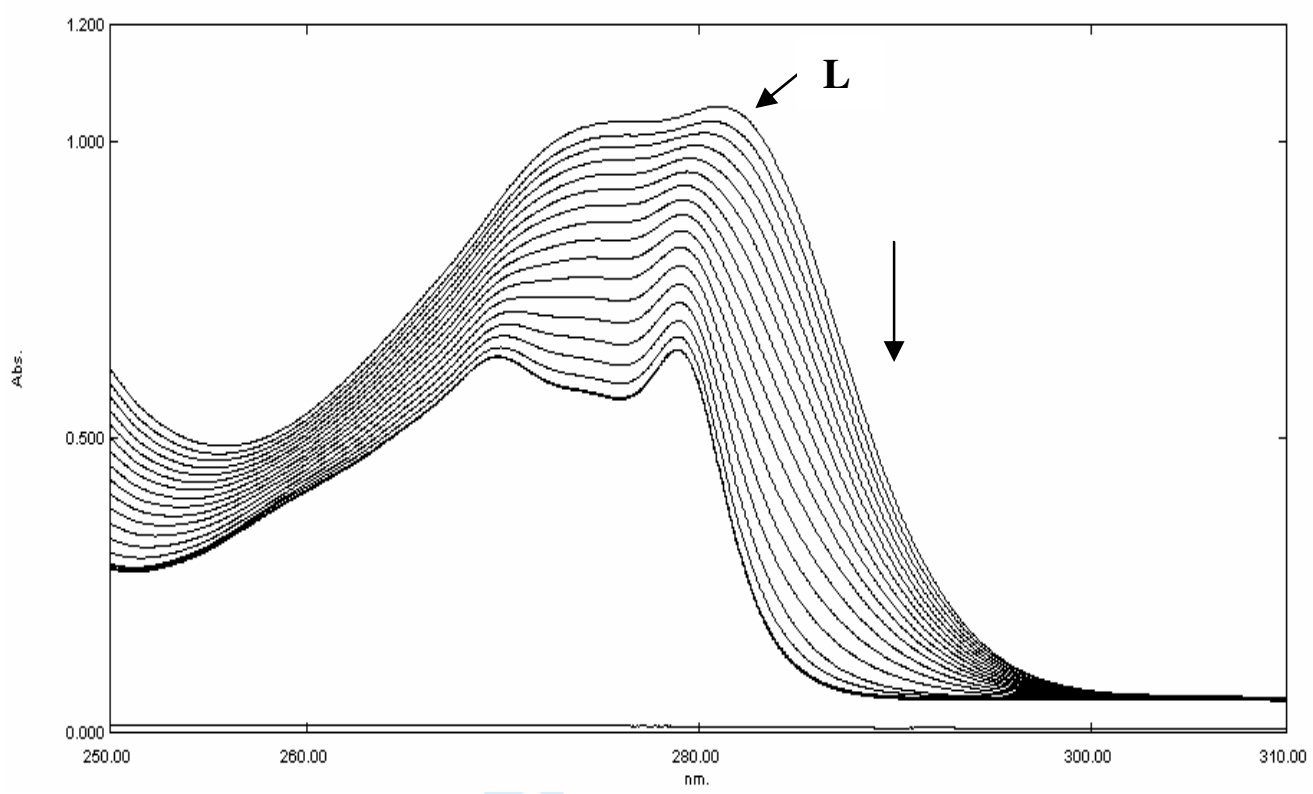

Figure 2

URL: http:/mc.manuscriptcentral.com/tandf/gsch Email: suprachem@mail.cm.utexas.edu 27 


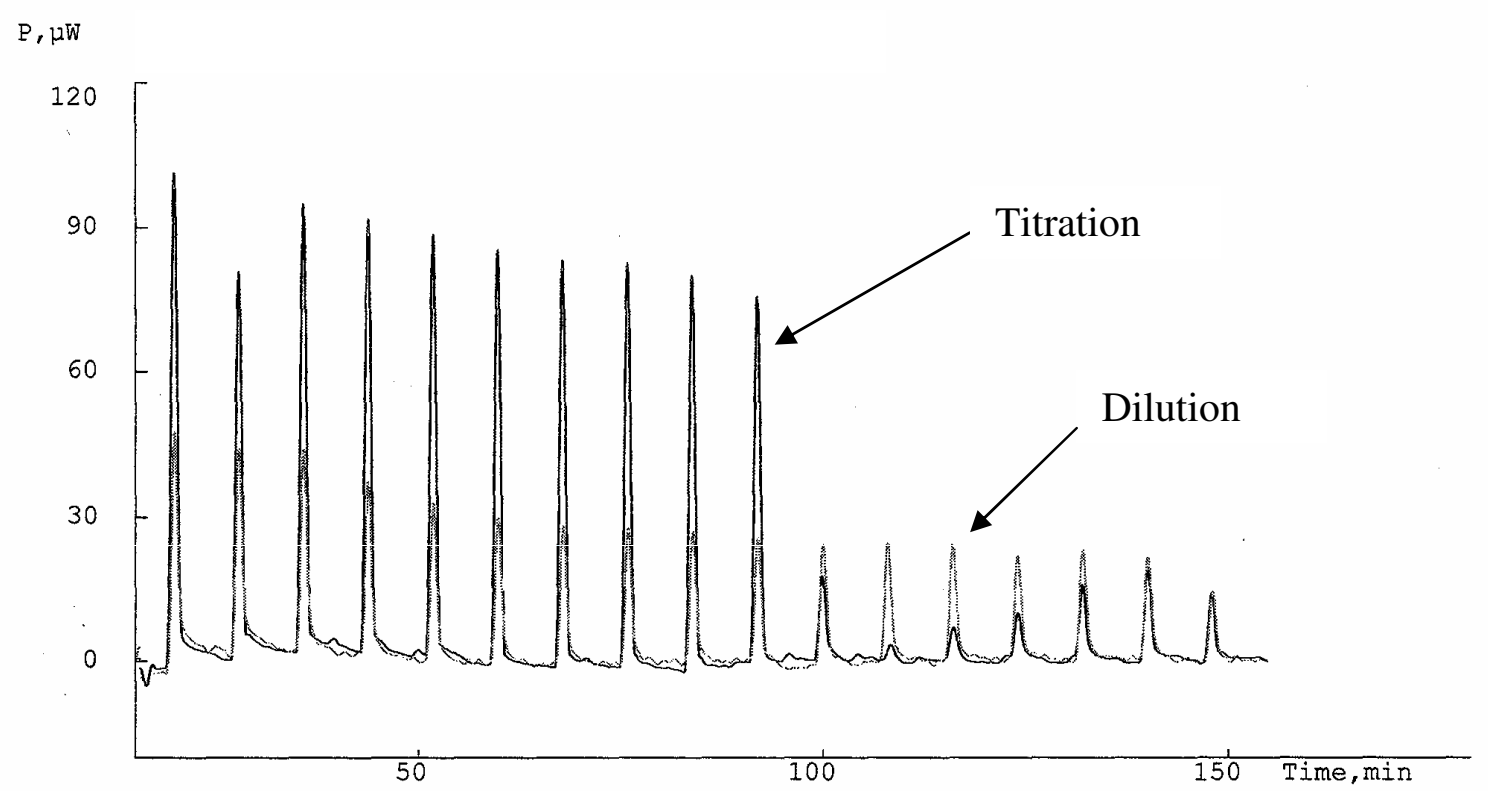

Figure 3

URL: http:/mc.manuscriptcentral.com/tandf/gsch Email: suprachem@mail.cm.utexas.edu 28 


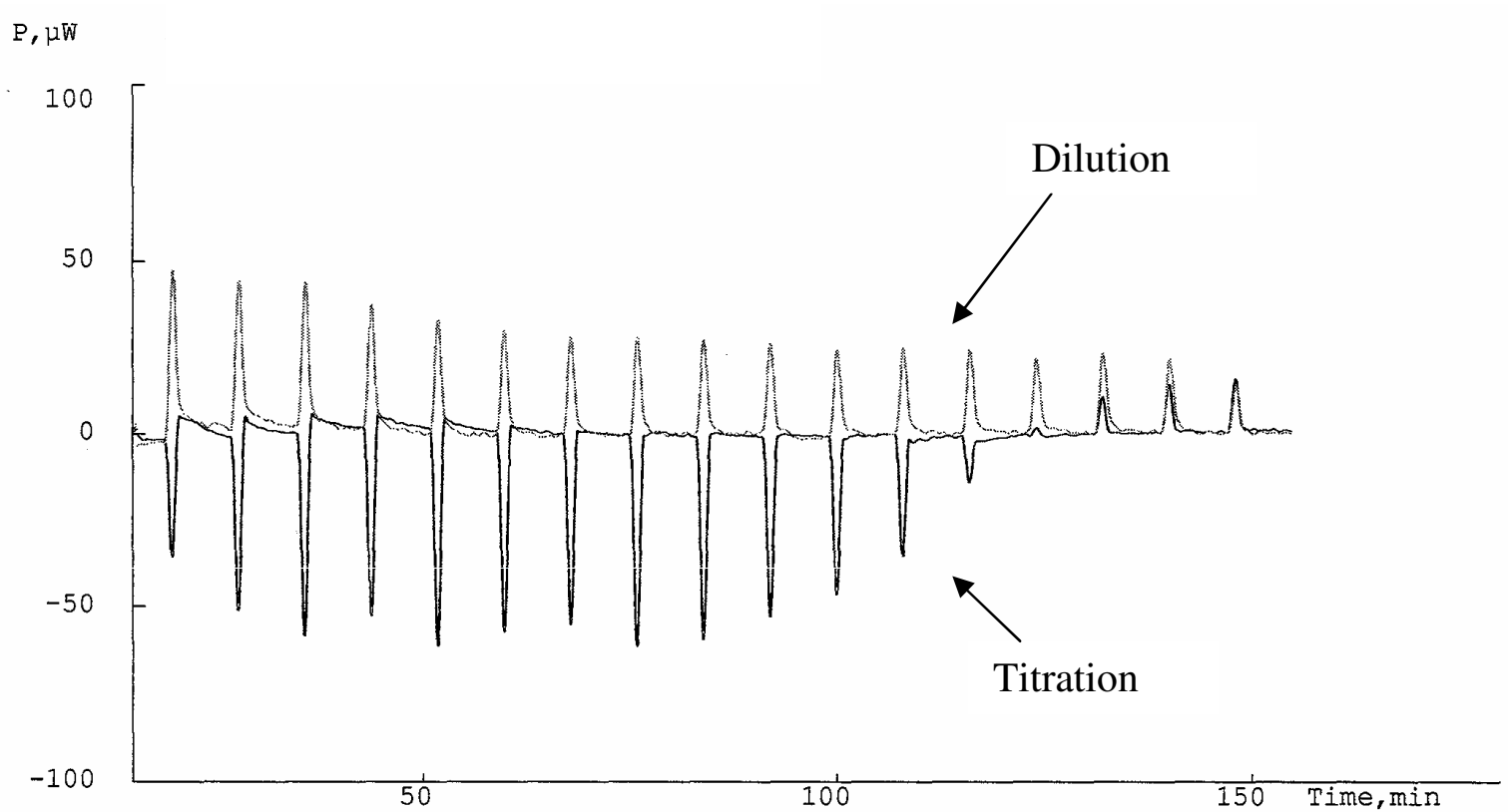

\section{Figure 4}

URL: http:/mc.manuscriptcentral.com/tandf/gsch Email: suprachem@mail.cm.utexas.edu 29 
(d)

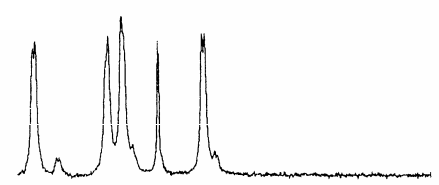

(c)

(b)

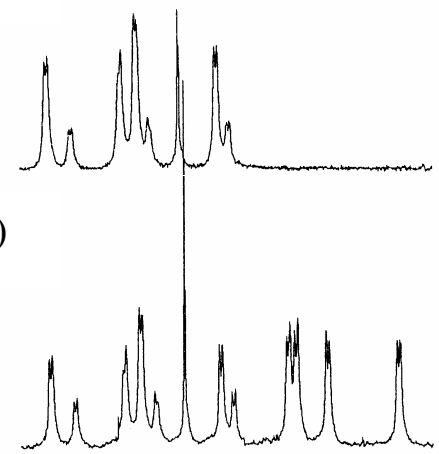

(a)

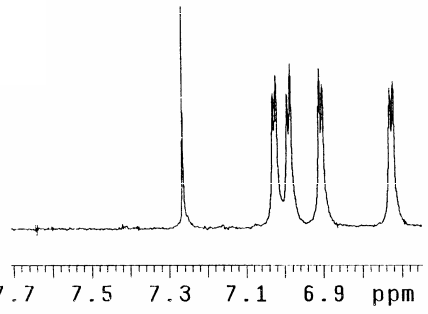

Figure 5

URL: http:/mc.manuscriptcentral.com/tandf/gsch Email: suprachem@mail.cm.utexas.edu 30 


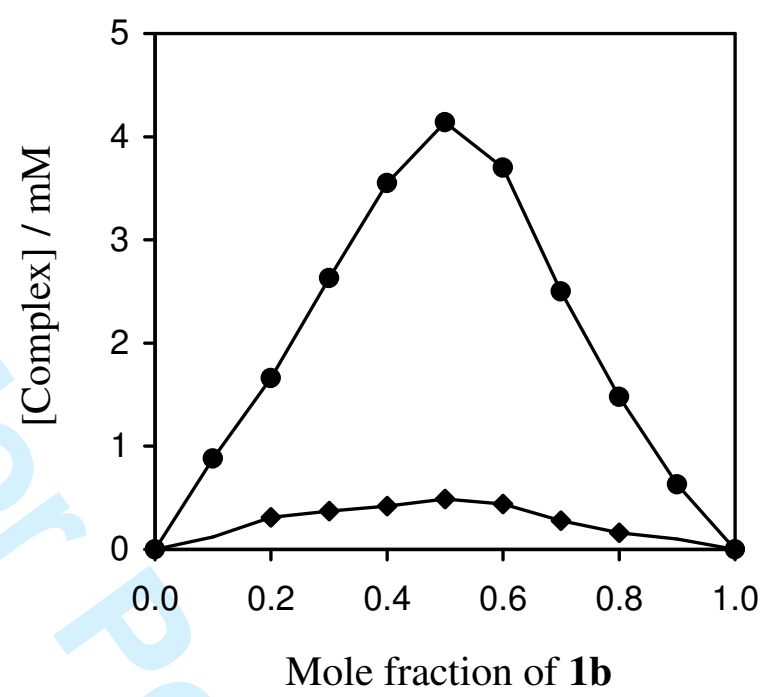

- Complex A

- Complex B

Figure 6 

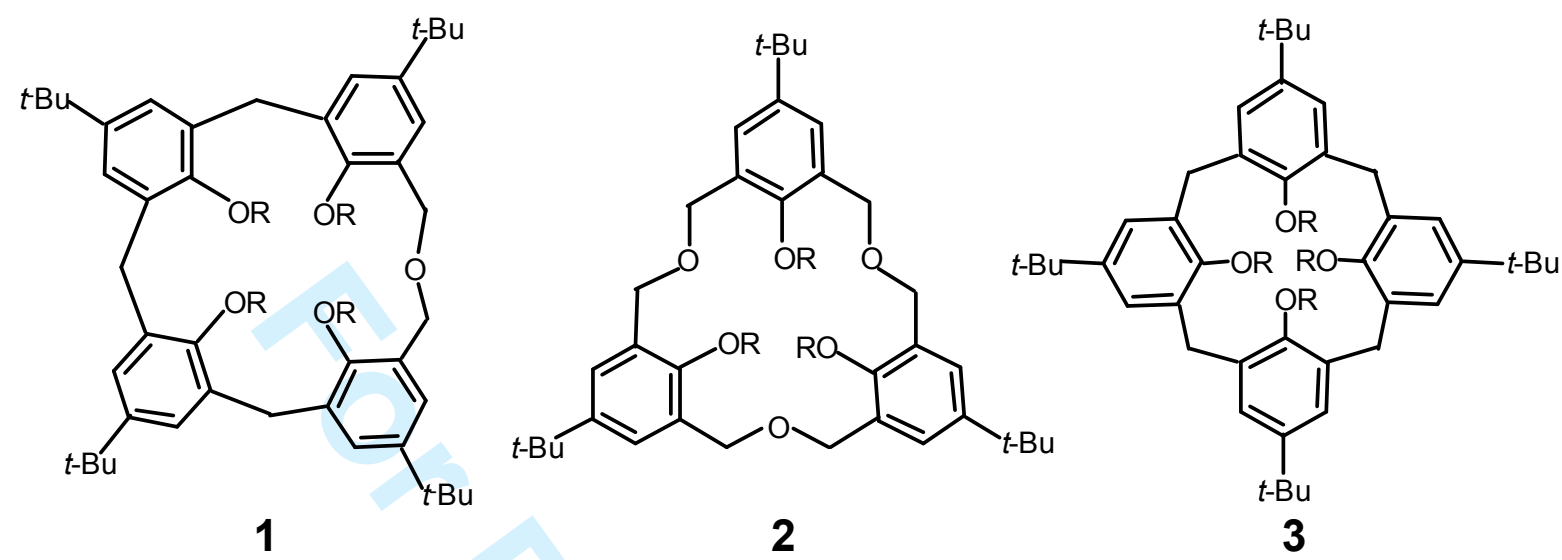

a $\mathrm{R}=\mathrm{H} \quad$ b $\quad \mathrm{R}=\mathrm{CH}_{2} \mathrm{CONEt}_{2}$

Figure 1 


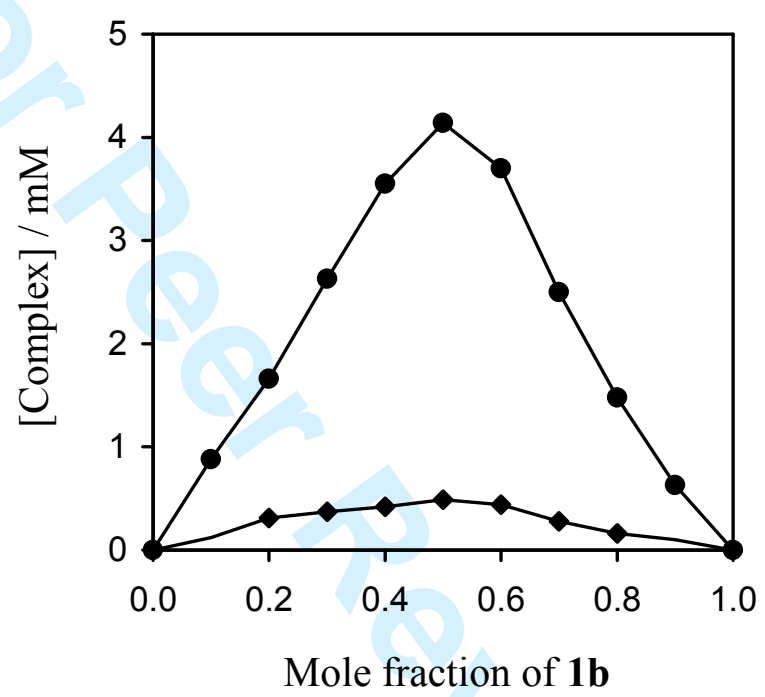

- Complex A

- Complex B

Figure 6 